\title{
Some Nutrient Deficiency Symptoms Displayed by Dracaena deremensis 'Warneckii' under Greenhouse Conditions and Their Subsequent Effects on Leaf Nutrient Content ${ }^{1}$
}

\author{
Saulo J. Rodríguez, Héctor R. Cibes, and Jaime González-Ibañez:2
}

\begin{abstract}
Thirty well-rooted cuttings of Dracaena deremensis 'Warneckii' Engler, were grown in 3-gal porcelain crocks using a solution culture method, with differential treatments consisting of solutions deficient in either $\mathrm{N}, \mathrm{P}, \mathrm{K}, \mathrm{Mg}$, $\mathrm{Ca}, \mathrm{S}, \mathrm{Fe}, \mathrm{Mn}$ or $\mathrm{B}$. An extra set of plants received a complete nutrient solution for comparison. By the end of the experiment, characteristic deficiency symptoms of only N,P, Ca, and Fe developed as follows: A lack of $N$ induced a reduction in top growth and a pale green foliage. Younger leaves tended to be long and narrow with wavy margins. They also developed black spots along the typical white band near the margin. The root system of such plants was abundant and fibrous. New suckers were weak and few. Phosphorus deficiency was characterized by a rosettelike arrangement of the younger leaves. Necrotic spots like the ones developed under $\mathrm{N}$ deficiency were also present. These eventually broke down giving the leaves a ragged appearance. Margin serration occurred in the younger leaves, specially in the basal portions. On the other hand, the mature leaves developed numerous rustlike pustules. New shoots were deep green in color and few in number. Growth of plants lacking Ca was drastically reduced. Young, as well as recently mature leaves, were affected by severe marginal serration. As the deficiency became more acute, numerous brown spots appeared along the margins of older leaves. As they increased in size, they progressed either toward the tips or the midrib, finally involving the whole lamina. Rustlike pustules similar to those exhibited by the minus- $P$ plants also were present in some of the oldest leaves of plants lacking $\mathrm{Ca}$. New shoots looked weak with blackish leaflets. Fe-deficient plants manifested a severe chlorosis, which appeared early in the young leaves. Some of the chlorotic leaves developed necrotic spots along the basal portion. As they increased in size the whole leaf was invaded.

The concentration of the particular missing element in the leaf tissues was lower in plants grown with the element withheld than in the controls.
\end{abstract}

\section{INTRODUCTION}

The commercial production of ornamental foliage plants is rapidly developing into a very lucrative agricultural enterprise for Puerto Rico. González Villafañe and Cucalón (2) found in an economic study of the ornamental plant business in 1971-72, that a total of $6,575,765$ units were exported to the U.S., valued at $\$ 906,347$. The Dracaenas were the single most important plants shipped to that country. Since then, the demand has increased enormously for the :hove-mentioned species as well as for other plants. This tendency has permitted the

1 Manuscript submitted to Editorial Board March 29, 1977.

${ }^{2}$ Horticulturist, Phytophysiologist, and Assistant Biologist, respectively, Agricultural Experiment Station, Mayagüez Campus, University of Puerto Rico. Rio Piedras, P.R. 
Commonwealth Department of Agriculture to predict annual exports of over $\$ 50$ million of ornamentals in the near future.

However, few studies have been performed locally with ornamental foliage plants. This is specially true in relation to their nutritional status. So far, the only investigations of this nature conducted in Puerto Rico are the following: Samuels and Cibes (6) on the Fe chlorosis of Dracaena sanderiana and its control; Cibes and Samuels (1) on the mineral deficiency symptoms displayed by $D$. sanderiana and $D$. godseffiana; and that by Rodríguez and Cibes (5) on the effects of five levels of $\mathrm{N}$ at six shade intensities on $D$. deremensis. Elsewhere, Poole and Conover (3) studied a foliar chlorosis of this last species which was correlated with the fluoride content of plants propagated in various media.

\section{PROCEDURE}

Well-rooted cuttings of $D$. deremensis 'Warneckii' were planted in 3gal glazed stone crocks in the greenhouse. They were grown in recently distilled water for a period of 3 months. Thereafter, the distilled water was replaced by the differential treatments which consisted of the deficient nutrient solutions. The various nutrient deficiencies studied were the following: $-\mathrm{N},-\mathrm{K},-\mathrm{P},-\mathrm{Ca},-\mathrm{Mg},-\mathrm{S},-\mathrm{Fe},-\mathrm{Mn}$, and $-\mathrm{B}$. A complete nutrient solution treatment was included for comparative purposes. Each of the above-mentioned treatments was replicated three times in a randomized block design. The composition of the nutrient solutions used was according to Cibes and Samuels (1). Solutions were changed every week and aerated twice a day in a continuous set up. Extra shade was provided to plants by means of a $50 \%$ shade polypropylene cloth inside the greenhouse. Visual observations were made periodically to follow up the development of the deficiency symptoms with the various treatments. As soon as a deficiency was considered fully developed, the plants were harvested. They were color photographed and leaf sampled for a complete chemical analysis. The remaining stumps were left growing in the crocks for further obscrvations on regrowth of new shoots.

\section{RESULTS AND DISCUSSION}

Of all the deficiencies whose symptoms were intended for study in Dracaena deremensis 'W:arneckii', only four could be fully developed, namely: $\mathrm{N}, \mathrm{P}, \mathrm{Ca}$, and $\mathrm{Fe}$. The experimental plants grown under a lack of $\mathrm{Mg}, \mathrm{K}, \mathrm{S}, \mathrm{Mn}$, and $\mathrm{B}$ did not show the malnutrition symptoms. This came as a surprise, specially in the case of $\mathrm{Mg}$ and $\mathrm{K}$, since deficiencies of most of these elements usually can be easily inuced by the solution culture method. Even after the plants were cut back, the new growth 


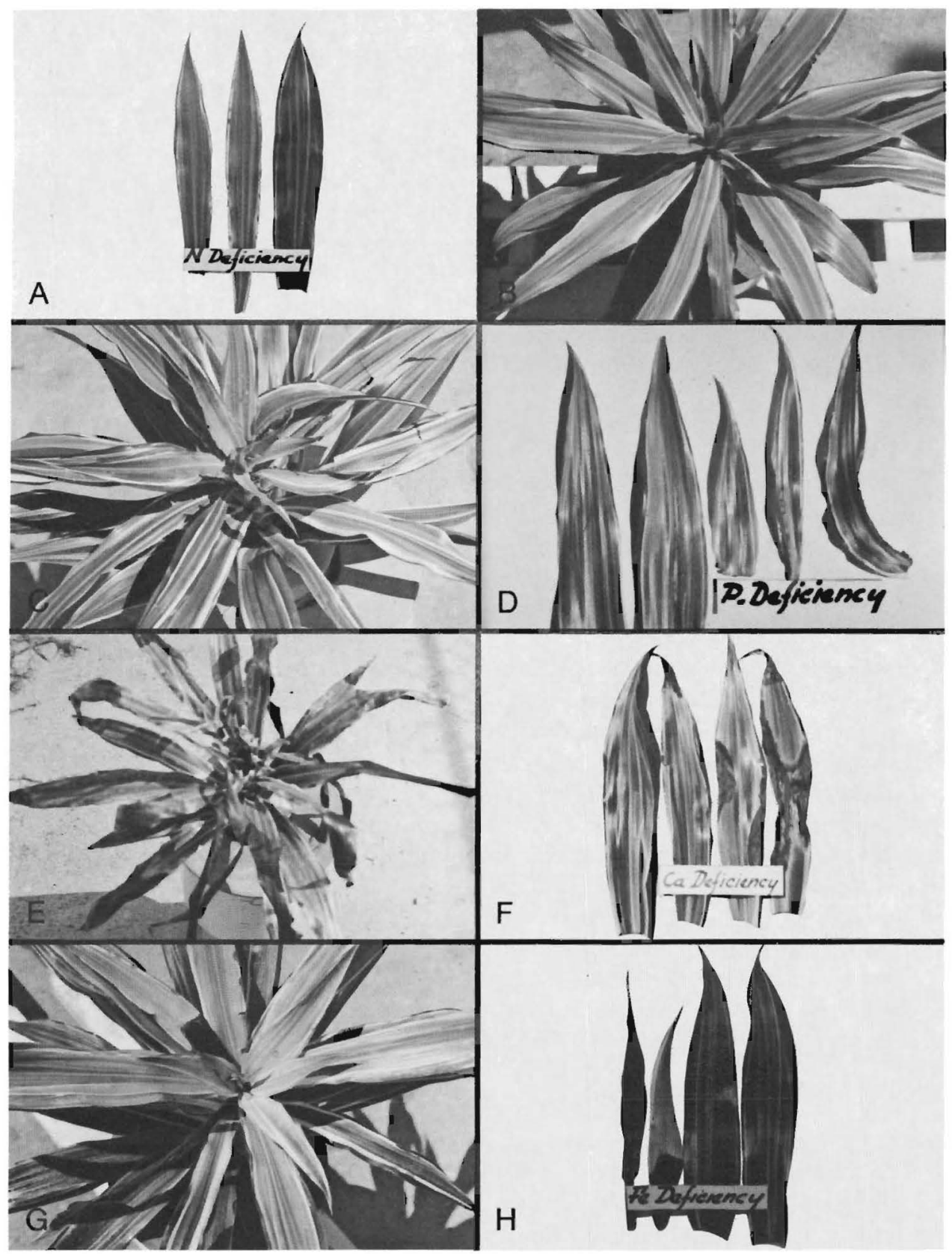

Fig. 1. $-\mathrm{A}-\mathrm{N}$ deficiency characterized by narrow, pale green leaves. B-Left-two leaves affected by a lack of $\mathrm{N}$. Notice the brown spots along the white stripe. Right-a healthy leaf. C-P-deficient plant showing small, distorted, serrated leaves. D-Left- 
looked completely healthy. The only explanation to account for the lack of response is that those plants had accumulated in the stems large amounts of the four above-mentioned nutrient elements and they were reusing them. Thus, the discussion of the results obtained will be limited to the stated four deficiencies.

\section{VISUAL SYMPTOMS}

\section{Nitrogen}

Usually, the visual symptoms characteristic of a lack of $\mathrm{N}$ are the first to appear in plants. This time, however, they coincided with those of $\mathrm{Ca}$ and $\mathrm{Fe}$. In the affected plants there was a severe reduction in growth. The absence of this element from the nutrient solution induced not only a reduction in the top growth but also caused a pale green coloration of the foliage (fig. 1, A). However, they never turned chlorotic as in other species. The young leaves tended to be very narrow with pronounced wavy margins. There was very little serration of the margins. In turn, the white strip characteristic of the species became mottled (fig. 1, B). The root systems of these plants were abundant and fibrous. The remaining stumps produced few suckers, which had a very weak appearance.

\section{Phosphorus}

$\mathrm{P}$ deficiency was characterized by a rosettelike arrangement of the young leaves (fig. 1, C). Tiny holes developed in these leaves, which later coalesced to form large necrotic spots along the white band. They also developed a serrated margin, specially at the basal portion. As the deficiency progressed, necrotic spots appeared throughout the leaf margins (fig. 1, D). These leaves were greener at the top half of the cane than at the basal half, with a mottled appearance of the intermediate section. In the acute phase of the deficiency, the apex of the oldest leaves necrotized badly in fully developed leaves. Leaves were coriaceous and brittle. The terminal buds were affected by necrotic

healthy leaf from plant under complete nutrient solution. Right-leaves from Pdeficient plant showing various stages of the deficiency. E-Plants severely affected by a lack of $\mathrm{Ca}$ in the nutrient medium. $\mathrm{F}$ - Left - healthy leaf from plant under complete nutrient solution. Right-leaves from Ca-deficient plant showing necrotic spots at tip and halfway along the leaf blade. These latter spots coalesced at the midribs. G-Fedeficient plant showing serration of leaf margins, brown spots along the white stripes, reduction in size of young leaves, rust pustules and dieback of the leaves from the base toward the tips. There was no chlorosis at first, but later a chlorosis developed in the new shoots coming out from the old stump. H-Left-Fe-deficient leaves showing dieback from the basal portion. Right-healthy leaf from plant with a complete nutrient solution 
spots in the rudimentary leaves. The root system appeared to be normal in growth and color.

\section{Calcium}

Clear-cut symptoms developed in plants under the minus-Ca treatment are shown in fig. $1, \mathrm{E}$. There was some reduction in growth. The young leaves and the most recently matured ones showed at least some marginal serration. Brown necrotic areas showed in the basal portion of affected leaves, progressing toward the tips, while in other instances this happened all the way around. On some occasions the necrotic spots developed halfway along the leaf blade, this time progressing toward the midrib. In this last case the necrotic condition divided the leaf blades into two portions: the upper and lower sections remaining green for a while. Ultimately they turned completely brown (fig. 1, F). The uppermost leaves of the minus-Ca plants developed a sort of ragged condition without manifesting any signs of necrosis. Old leaves exhibited numerous reddish pustules grouped together at either the base, middle, or tip sections. The young leaves were pliable and very thin. The root systems, however, did not present any abnormal condition. The remaining stumps produced poorly developed suckers with bleached leaflets.

Iron

The young leaves of the Fc-starved plants presented a bleached appearance apparently due to a lack of chlorophyll (fig. 1, G). A rustlike mottling developed in the fully grown leaves either at the base or apex of the leaf blade, visible on the upper as well as lower surfaces. Necrotic areas shown by young leaves usually started to develop at this basal portion, progressing upward until they extended throughout the whole lamina (fig. 1, H). The root system looked normal in growth and appearance. Sprouting suckers were very weak and bleached. Some of the leaflets presented necrotic spots along their margins.

\section{CHEMICAL COMPOSITION}

The effects of omission of the above-mentioned elements on composition of the experimental plants are shown in table 1.

\section{Nitrogen}

Leaf $\mathrm{N}$ content was lowest in the $\mathrm{N}$-deficient plants. There was no difference in this respect between the young pale and mature leaves. It seems that the $\mathrm{N}$ content of these plants was a little high to account for the severity of the symptoms. Young leaves with serrated margins of the minus-P plants showed the highest $\mathrm{N}$ level. This was higher than 
TABLE 1. - Mineral Composition of Dracaena deremensis 'Warneckii' leaves as affected by nutrient deficiencies

\begin{tabular}{|c|c|c|c|c|c|c|c|c|c|c|}
\hline \multirow{2}{*}{ Treatment } & \multicolumn{9}{|c|}{ Nutrient element composition - dry weight basis } & \multirow{2}{*}{ Remarks } \\
\hline & $\mathrm{N}$ & $P$ & K & $\mathrm{Ca}$ & $\mathrm{Mg}$ & S & $\mathrm{Fe}$ & Mn & $\mathrm{B}$ & \\
\hline & $\%$ & $\%$ & $\%$ & $\%$ & $\%$ & $\%$ & $P / m$ & $P / m$ & $P / m$ & \\
\hline Complete & 3.74 & 0.22 & 5.50 & 1.54 & 0.52 & 0.30 & 223 & 232 & 43 & Composite mature leaves \\
\hline$-\mathrm{N}$ & 1.96 & .21 & 4.90 & 1.77 & .62 & .28 & 163 & 395 & 33 & Young pale leaves \\
\hline$-\mathrm{N}$ & 1.90 & .25 & 5.06 & 1.51 & .53 & .31 & 639 & 213 & 45 & Mature leaves \\
\hline$-\mathrm{P}$ & 3.86 & .10 & 4.96 & 1.94 & .60 & .39 & 451 & 448 & 27 & Young leaves with serrated margins \\
\hline$-\mathrm{P}$ & 2.84 & .07 & 4.65 & 2.74 & .61 & .48 & 295 & 432 & 56 & Mature leaves with red mottling \\
\hline$-\mathrm{P}$ & 3.00 & .07 & 4.96 & 1.81 & .56 & .40 & 208 & 312 & 35 & Mature leaves \\
\hline$-\mathrm{Ca}$ & 3.12 & .25 & 5.28 & .57 & 1.01 & .20 & 177 & 621 & 26 & Young leaves with serrated and ragged margin \\
\hline$-\mathrm{Ca}$ & 3.36 & .18 & 4.96 & .32 & 1.55 & .34 & 239 & 707 & 40 & $\begin{array}{l}\text { Mature leaves with necrotic areas along margin } \\
\text { and apex }\end{array}$ \\
\hline$-\mathrm{Ca}$ & 2.90 & .17 & 4.33 & 2.72 & .84 & .32 & 280 & 458 & 59 & Normal leaves \\
\hline$-\mathrm{Fe}$ & 3.50 & .21 & 5.15 & 1.23 & .44 & .27 & 83 & 709 & 20 & Chlorotic young leaves \\
\hline$-\mathrm{Fe}$ & 2.92 & .16 & 4.21 & 2.70 & .80 & .28 & 301 & 454 & 61 & Mature leaves with rusty mottling along blade \\
\hline$-\mathrm{Fe}$ & 3.16 & .18 & 5.28 & 1.77 & .60 & .28 & 155 & 474 & 45 & Apparently normal leaves \\
\hline
\end{tabular}


the complete. The minus $\mathrm{Ca}$ and minus $\mathrm{Fe}$ plants had lower $\mathrm{N}$ values than the full nutrient ones.

Phosphorus

The lowest $\mathrm{P}$ accumulation was found in the leaf tissues of plants with a lack of this element. Generally speaking the young active leaves had a higher $\mathrm{P}$ value regardless of the deficiency involved.

\section{Potassium}

All leaf samples showed a very high $\mathrm{K}$ content regardless of the deficiency involved. It is amazing how this plant can accumulate such high amounts of $\mathrm{K}$ to enable it to grow for such a long period of time without showing deficiency symptoms, as was the case of the minus-K plants. This is a clear-cut example of what is referred to as luxury consumption in plant nutrition.

\section{Calcium}

The minus $\mathrm{Ca}$ treatment induced the lowest Ca level of all treatments in young and mature leaves with deficiency symptoms. The absence of this element had little effect upon the $\mathrm{K}$ level. However, the suppression of $\mathrm{Ca}$ from the nutrient solution increased the $\mathrm{Mg}$ content twofold. Rodríguez and López (4) obtained somewhat similar results with $D$. sanderiana.

\section{Magnesium}

The lowest $\mathrm{Mg}$ content was obtained under the minus-Fe treatment in tissue sampled from young white leaves. Nonetheless, this did not differ much from that of the controls. The highest $\mathrm{Mg}$ level was obtained when Ca was suppressed from the nutrient medium, especially in mature leaves with necrotic areas and young leaves with serrated margins.

Sulfur

The presence of $\mathrm{S}$ in leaf tissues was not much affected by the various treatments.

\section{Iron}

The Fe deficiency was directly responsible for the low Fe content in the chlorotic young leaves. This value was the lowest induced by the other treatments. Iron content ranked very high in the mature leaves of the minus- $\mathrm{N}$ treatment. It was also high in the young leaves with serrated margins in plants with lack of $\mathrm{P}$. On the other hand, $\mathrm{Fe}$ was 
present in somewhat low amounts in young leaves of minus- $\mathrm{N}$, mature leaves of minus-P and young leaves of minus-Ca treatments, respectively.

\section{Manganese}

The least Mn concentration was detected in the controls and mature leaves of plants under a lack of $\mathrm{N}$. It was high in the rest of the treatments, specially in chlorotic young leaves of minus-Fe and mature leaves with the necrotic areas of minus-Ca treatments.

\section{Boron}

The B content did not vary as much as the two other minor elements. The lowest level of this element was detected in the chlorotic young leaves of minus-Fe. B content was relatively low in the young leaves with serrated and ragged margins of minus-P and minus-Ca plants.

In conclusion, definite visual symptoms for $\mathrm{N}, \mathrm{P}, \mathrm{Ca}$, or Fe deficiency were clearly developed in $D$. deremensis 'Warneckii' plants under greenhouse conditions. No other visual deficiency symptoms were observed, possibly because the requirements are low and the accumulated nutrients in the cutting were sufficient for growth. In most cases, leaf analyses corroborated the visual deficiency. In others with no visible deficiency symptoms, the leaf sample gave a low nutrient content. The leaf nutrient composition can be used as a diagnostic tool many times when visual deficiencies are not yet apparent.

\section{RESUMEN}

Esquejes de Dracaena deremensis 'Warneckii' se establecieron en soluciones carentes de N, P, K, Ca, Mg, S, Fe, Mn, y B. En estas soluciones y en condiciones de invernadero solamente los esquejes con carencias de $\mathrm{N}, \mathrm{P}, \mathrm{Ca}$ y $\mathrm{Fe}$ desarrollaron sintomas.

La carencia de $\mathrm{N}$ se distinguió por una reducción e tamamo de la planta y un color amarillento generalizado. Las hojas nuevas eran alargadas. La estría blanca característica de la especie mostraba algún moteado. La planta desarrolló un sistema radical profuso y fibroso. Los tallos secundarios después de la poda eran muy débiles y pálidos.

La carencia de Ca se distinguió por márgenes serrados en las hojas superiores. Varias hojas mostraron necrosis progresiva de la punta hacia la base o del margen hacia el centro. Ocurrió estrechez de las hojas superiores o nuevas y encogimiento del margen foliar. Los tallos secundarios demonstraron poco desarrollo y ennegrecimiento de las hojuelas.

La carencia de Fe ocurrió en las hojas nuevas en una clorosis o moteado. Las hojas maduras mostraban puntos necróticos rojizos parecidos a pústulas tanto en la haz como en el envés. Los tallos secundarios se desarrollaron completamente pálidos, albinos.

La carencia de P se caracterizó por la formación de rotitos en el tejido foliar blanco, que más tarde se extendieron ocasionando rompimiento a lo largo de la franja blanca. Las hojas maduras mostraron puntos rojizos similares a los de carencia de hierro. Las hojas jóvenes y nuevas mostraron un color verde en el ápice con una zona pálida en la base. La zona intermedia muestra algún moteado. Los márgenes de las hojas nuevas se muestran serrados. Los tallos secundarios desarrollaron poco y eran de un verde intenso.

Los análisis de las muestras foliares corroboraron la carencia nutricional. 


\section{LITERATURE CITED}

1. Cibes, H., and Samuels, G., Mineral Deficiency Symptoms Displayed by Dracaena godseffiana and Dracaena sanderiana Grown under Controlled Conditions, Tech. Paper 29, Agric. Exp. Stn. Univ. P.R., 1960.

2. González-Villafañe, E., and Cucalón, M., Análisis de las Importaciones y Exportaciones de Plantas Ornamentales y Flores de Puerto Rico, Est. Exp. Agri. Univ. P.R., Bol. 235, 1974.

3. Poole, Richard T., and Conover, Charles A., Foliar Chlorosis of Dracaena deremensis Engler cv. Warneckii Cuttings Induced by Fluorides, Hortic. Science 9(4): 378-9, 1974.

4. Rodriguez, S. J., and Rivera-López, C., Influence of Nitrogen Applications on Leaf Nutrient Content of Dracaena sanderiana (Hort) Leaves, J. Agric. Univ. P.R. 60 (3): 344-7, 1976.

5. — and Cibes, H. R., The effects of Five Levels of Nitrogen at Six Shade Intensities on the Growth and Leaf-Nutrient Composition of Dracaena deremensis 'Warneckii', Engler, J. Agric. Univ. P.R. 61(3): 305-13, 1977.

6. Samuels, G., and Cibes, H., Iron Chlorosis on Dracaena sanderiana, J. Agric. Univ. P.R. 37(4): 265-72, 1953. 